\title{
The political role of intellectuals
}

\author{
Anna Yu. Karpova ${ }^{1,}$, Natalyia N. Meshcheryakova ${ }^{1}$, and Aliona I. Chudinova ${ }^{1}$ \\ ${ }^{1}$ Tomsk polytechnic university, 634050 Lenina str., 30, Tomsk, Russia
}

\begin{abstract}
The article points out that the role of intellectuals in society and its relationship with the government amid the unfolding global financial crisis affected all spheres of social life. The authors proceed from the assumption that a change in the very nature of society, the increasing complexity and accelerating social dynamics, involves changing social community and "intelligentsia" in terms of structural and functional features. It is the rate of flow of social processes in the modern and continuously establishing society has led the authors to the treatment allocation of functional features, which constitute the social community of intellectuals. We believe that intelligentsia carries two major functions in society: stabilization of its social system and the function of its critical analysis. These features obviously have a different direction of its vector, hence, we base our reasoning on the ideas of Gramsci and distinguish its two types: conventional and organic.
\end{abstract}

\section{Introduction}

Governance still needs support of broad social forces even if it is reluctant to admit it. It was one of the key conclusions heard at the last XXIII IPSA World Congress of Political Science held in Montreal, July 2014 [1]. It was noted at the congress that when the phenomenon of governance faces the challenges, which appeared in the conditions of globalizing society, multifaceted phenomenon of governance requires its rethinking. According to the leading expert, professor from the University of Southampton, Rod Rhodes, it is necessary to rediscover the statecraft [2]. Currently, management authorities represent various interests of corporations, business elites, political leaders and parties. Due to the expansion and embranchment of these authorities administration system is becoming more complicated and increasingly difficult for a common citizen to interpret and understand. As long as intellectuals have always been the mediators between public authorities and society, performing the function of the effective administration of society directly depends on whether this social group fulfills its political role. The same way like politics cannot do without ideology; the dominant elite cannot do without the mediator and implementation of its interests, ideas and pursuits. It is especially topical now that humanity is in the transitive period of its development.

In their congressional reports international scientists noted such a rising risk as possible degrading in democratic qualities of political systems as a result of the growing impact and opportunities to make decisions by technocratic executives, administrative representatives

\footnotetext{
${ }^{\text {a }}$ Corresponding author: aic@tpu.ru
}

and experts. But it is one of directions. There are other ones.

Reflections about the political role of intellectuals intensified against the backdrop of the economic crisis that began in 2008 and is now worsened by a severe political crisis [3]. International researches believe that only intellectuals are able to give intellectual answer to the crisis. It is no wonder that congress participants were very excited and supportive to meet the documental "Blueberry soup" directed by Eileen Jerrett, Icelandic film director, and shown as the part of main program forum [4]. The work tells about the origin of Icelandic grassroots movement after the 2008 crisis in terms of which folks required more public integrity from their leaders and bankers. The intentions of the folks are aimed at understanding everything happening around. It is the loud appeal to act instead of descending into apathy. Icelandic society brings back the headship over the government and demands instant changes to save the country. The overall conclusion is that Iceland economic collapse shows that every nation can face radical economic turbulence. But according to Thorvaldur Gylfason, professor from the University of Iceland, "financial crisis can break up a company and the fates of some individuals but it cannot destroy a country" [5]. Iceland paradox is in that intellectuals could consolidate social forces and steer them in the right direction within a short time. Professor Gylfason highlighted that "Finances make up just $4-5 \%$ from all the national wealth and its main part is human and social capital... Iceland... turned to have enough power to save it" [5]. 
Turning back to current solving the problem about the role of intellectuals by social and political science at all we will remind that it recently gained topicality against the backdrop of unfolding world crisis. It was not coincidentally that we started the article from describing the key problems addressed at the XXIII Worldwide congress on political sciences as it is just due to intellectuals (as a special social community) who government represents its interests and pursuits by means of "calculating success" [6] into the public conscience.

In the given article we put the task to define the political role of intellectuals in modern society based on the works of philosophic and sociological classics and modern political experts. We chose offered by A. Gramsci dividing traditional and organic intelligence as the hard point to understand political role of the intellectuals in modern complicated society. We offer our seeing for the phenomenon of the latter one in dynamic social development of society, and namely, taking into account the temporality of historical process as integral social development characteristic. It reveals in coincidence of interests, combining and permutating constellations of interests among traditional and organic intellectuals in modern complicated society.

We implement our own formulated conception about the political role of intellectuals for the analysis of Russian society with regard to its specific features.

\section{Materials and methods}

Methods: This paper is greatly based on historiographical research that includes comparativehistorical and typological methods.

Materials: Defining social and political role of intellectuals in the works of M. Foucault, M. Bourdieu, R. Merton

Changing social reality leads to transforming and rethinking social roles. One of the first scientists who spoke about it in relation to intellectuals was Michel Foucault. He contradistinguished "universal" intellectual, the bearer of educational ideas, to "specific" intellectual who appeared as sociocultural type after the Second World War [7]. According to the author, one type is gradually substituting the second one. Knowledge and truth are eternal values for the universal intellectual. There is something messianic in his image as he should bring values-blessings to people and it is no wonder that according to M. Foucault universal intellectual's maximally complete personification is a writer. Foucault describes Voltaire and Rousseau as the prototypes of "universal" intellectuals as they were the bearers of values and had universal minds. Universal intellectual contradistinguishes universalism of justice and nondiscrimination law to governance, despotism, delusions and the arrogance of wealth. Foucault gives the example of a specific intellectual who is the scientist and the expert; it is the scientist and physicist J. Robert Oppenheimer who uses his knowledge, skills set and attitude to truth for political struggle. Specific intellectuals can develop political struggle as they do not have global strategy in contrast to universal intellectuals who have ideology.

According to Foucault, universal intellectuals manifested themselves in a very bright way from the $19^{\text {th }}$ to the middle of $20^{\text {th }}$ centuries and they gradually lost the role that Foucault assigned to them, that is to recognize and transfer universal understandings for truth and justice. Specific intellectuals came to replace them. He points out that the most important thing in performing political role for the intellectuals should be fulfilling political duties and calls this "the politics of truth" and "the regime of truth". Foucault implies that every society has intellectuals who should convince populace about the difference between true and false, that is between the announces of politics, what kind of sanctions, methods and procedures they use and what the truth really is. He calls this "the regime of truth in general politics of truth". According to him, truth should be produced under the control of intellectuals. Foucault defines outstanding characteristics of intellectuals: class position, environmental specific features, specific features for the politics of truth and, by doing this, he, as if completes the circle of those who contemporarily worth entering this group.

P. Bourdieu is at one with M. Foucault and his image of a "specific intellectual". It is just him who is peculiar (through the prism of locality in his professionalism) to make conclusions tending to universality. He depends on bureaucratic arts patronage. But these are just intellectuals who have the privilege to tell the authorities "no". Critical moods of intellectuals result from depending the field of cultural production on political and economic authorities. "Thanks to strengthening their autonomy (and, by this, their freedom in relation to authorities) intellectuals can intensify the efficiency of political action the aims and means of which find their substantiation in specific logics for the fields of cultural production" [8]. According to Bourdieu, the efficiency of symbolic violence is often provided with our ignorance of its mechanisms. And, if to follow this context, even their simple revelation with scientific analysis is already social critics that society needs for its (society) perfection [9]. "The work on changing your own and other people thinking appears to be the sense of existence for intellectuals" [10], Bourdieu writes. M. Foucault has similar point of view. As one can see, though M. Foucault and P. Bourdieu both admit the transformation of modern intellectual into the expert of his particular professional sphere these scientists reserve the right for the intellectuals to tell their critical opinions on a wider range of issues. It is just the right that is provided with the significance of cultural capital peculiar to intellectuals.

It was just R. Merton [11] who wrote about the difficulties in personal and group choice, (about) the difficulties that faced intellectuals on the account of bureaucratic activity in recruiting intellectuals in guiding lines. Those who agree to be the part of authorities experience the change of values and become specialists. Though some part of such intellectuals consider themselves to be the experts and hope to bring their knowledge in decision-making process and the latter one 
will be qualitatively improved. The others initially bend themselves for the executives and are ready to implement any politics imposed on them. There are also such intellectuals who prefer working in University Departments as it let them avoid direct dependence on business and authorities. But this choice dooms them to become outside observers instead of history-makers

It begs the question: is this conflict unsolvable?

The first: you are the outside observer of the happening political processes and save critical position in relation to them and you are the pointy head, then;

The second: you let being involved with some administrative project, join a bureaucratic corporation and, by doing so, if to follow the logics of socio-political discourse you stop being the pointy head in the strict word sense.

Defining socio-political role of intellectuals in Gramsci`s work "The Prison Notebooks"

We decided to resort to Gramsci`s work "The Prison Notebooks" to find the answer to the question. His work is amazingly relevant today despite its century-old remoteness and his views on the role of intellectuals in public life are of particular immediate interest. The confirmations of these are the publications in western scientific periodicals and in political and sociological congress proceedings. T. Suzuki [12], the Japanese author, relies on A. Gramsci`s standing and believes that the signs that define intellectuals as a social strata are incurred social liabilities and meeting the last ones gives intellectuals the right to play the leading role in public life. Not everybody plays socially organized functional role of an intellectual. Active interactions of common people mostly comply with individual characteristics though intellectuals, on the contrary, create relations and participate in socially active relations whether they are in economic, social or political spheres [12]. One more example from the proceedings for XVIII ISA World Congress of Sociology is the publication of Bamyeh Mohammed «The Social Role of Organic Intellectual: Four Amendments to Gramsci» [13]. The author outlines four corrections to Gramsci to considerate them as intended for researching the social role of intellectuals in Middle East. The author rests on Gramsci's work and offers the measurements of "organic intellectual" under the following criteria:

- firstly, the representative of this category can be both the native of a definite social group and the founder of a similar social group;

- $\quad$ secondly, his activity is more efficient if it interlinks to intellectual needs of complicated current reality but not just to some ideological program;

- thirdly, the representative of organic intellectuals is inclined to "high culture" which is considered (by him) as a link of his social program but not as some fetish;

- fourthly, the effectiveness of the organic intellectual can be measured with the extent to which his audience perception of reality changes even if he or she states that is aimed to save this perception.

Our attention draws the fact that the author interprets Gramsci`s ideas without appropriate exactness. For example, he mixes the definitions of organic and traditional intellectuals and their social roles that were described by the Italian scientists in details. But giving additional sense to a text or a theory is not indicative by itself. We try to find the answers for the very heartpounding topical questions in the century-old works of the scientists. Bamyeh [13] concludes that the social role of organic intellectuals intensifies at the time when one should balance at the interface of innovations and dedication to traditions. He states that the representatives of this group are more eligible than someone else to perform this task.

Acceleration and complication of social dynamics, disequilibrium and low predictability of social system behavior and growing risks have escalated the question about the role of intellectuals in modern complicated society. The importance of this role is growing in connection with the need to give the intellectual answer to the crisis. According to Bamyeh [13] special competence of intellectuals is the ability to connect traditions and innovations harmoniously and Suzuki [12] understands it as the readiness to willingly incur social liabilities in various spheres of social life. It is should be noted that three authors out of ten reports in the proceedings of XVIII ISA World Congress of Sociology rest their works on the ideas of A. Gramsci (XVIII ISA World Congress of Sociology. 2014, [14]) in the session «Intellectuals and Politics» (RC16 Sociological Theory).

Antonio Gramsci entered the history as philosopher, politician and creator of the theory of revolution where the key part is the theory of hegemony. He made the grandiose attempt to research the origin of intellectuals in different countries and to define the social role and functions of intellectuals in his work "The Prison Notebooks". Despite the fact that the main task of the philosopher was to study the problems connected to the formation of Italian intellectuals he comparatively analyzed the origin of intellectuals in different countries that let him define the forms of organizations and the types of intellectuals. We will briefly mention the most essential aspects of his work and will point up those Gramsci`s suppositions that allow to come closer to the understanding the political role of modern intellectuals.

\section{Traditional and organic intellectuals}

We will start from the brief review for the theory of hegemony in Gramsci`s work as it is just this theory that contains key moments to understand the role of intellectuals.

State government is based on the two rocks: power and consent.

Hegemony appears only under the condition when such a level of active consent is reached when citizenry willingly wish the same as the ruling class wishes.

Hegemony is continuous "molecular process" wherein undermining political stability leads to the loss or the establishment of hegemony. It runs not as the overt class struggle but with changing the consciousness of the most people in the line that is necessary for the 
ruling class. Both the ruling class defending its hegemony and revolutionary forces that have developed to fight for their hegemony must compete for changing the consciousness of the most people, that is the thoughts and the moods of the populace.

"Cultural heart" is the base of hegemony. It helps to create the "stable collective will" which is the guarantee for the stability of the current political order... Revolution appears in case of "molecular aggression" on the "cultural heart" and, consequently, "collective will" is broken and transition to the new political order takes place. Gramsci's understanding of "cultural heart" includes all the complex of current views about the world, traditions, beliefs but these are just intellectuals who he considers to be the base of the "cultural heart".

"Molecular aggression" is the flow of endlessly repeated information (through books, journals, newspapers, gossips) and duplicating the same assumptions that intentionally break the "cultural heart".

According to Gramsci if you look for the answer to the question why we need intellectuals it is necessary to understand why various societies have such a layer as intellectuals. To explain this we will briefly mark the main theses of his work:

- forming any social community (class, group) happens based on the definite economy;

- $\quad$ any class cannot separate and become independent without the organizers;

- the roles of organizers have theorists, ideologists who produce and distribute the ideas that organize the given class;

- the process of forming intellectuals has not spontaneous but explicable character: “... though every "essential" social group when coming into the historical arena from the preceding economic basis as the product of its development found - at least it happened in the history before now - earlier appeared categories of intellectuals that even acted as representing the continuity of historical development, the continuity that cannot be broken with even the most radical changes of social and political forms" [15];

- there are two types of intellectuals: organic and traditional. Organic intellectuals appear in the layers that are currently the most socially active. Traditional intellectuals are formed for ages and exist during a long historical period;

- intellectuals depend on the social layer that generates it, consequently, it forms the ideology that reflects the needs of the given social community;

- traditional intellectuals assume the Utopian attitude ascribing some abstract "special qualities" to themselves that in itself leads to insulation and “... is not left without extensive consequences in the sphere of ideology and politics" [15];

- "Cultural heart" includes both organic and traditional intellectuals and what is more, Gramsci believed traditional intellectuals to be of great importance for society and he thought that any social group, fighting for the hegemony establishment, strives to bring just traditional intellectuals on its side.

\section{Results and discussion}

\section{Traditional and organic intellectuals}

Russian sociopolitical sciences have the tendency to look at intellectuals as at the sociocultural phenomenon as just about exclusive result of Russian history and culture. It is as if in the West (the East is forgotten at all) where there is social community of intellectuals whose functional role in society is carrying out such activities that require high level of education and professional qualification. And Russian intellectuals are the bearers of mission, "the salt of the Russian land" whose differential characteristic - as Bulgakov wrote - is "striving to save humanity". Historical fate of Russian intellectuals is quite specific and formed on the basis of crisis. "The first steps of Russian intellectuals on the way to enlightened consciousness but not revolution was accompanied with victims and sufferings, jail and hard labour" [16].

The definition "intellectuals" itself is still polysemantic and it did not get a deeply-rooted definition in Russia as it is complicated, heterogeneous and contradictory phenomenon. Starting from Cicero the word intelligens (Lat. "understanding, thinking, reasonable") had been used just in this meaning for many centuries up to the $\mathrm{XIX}^{\text {th }}$ century. The new interpretation for the definition appeared in the end of the XIX ${ }^{\text {th }}$ century. Dahl's explanatory dictionary defines intellectuals as "reasonable, educated, mentally developed part of locals" [17]. At about this time the journalist P. Bobrikin announced himself to be the discoverer of the new understanding for the definition "intellectuals" as a special social group, the highest educated social layer having high intellectual and ethical culture.

Many scientific discussions are dedicated to studying the genesis of the definition "intellectuals". Despite that the majority of researchers points at the "Russian roots" of social understanding for the given notion there is opinion that "... intellectuals as social phenomenon goes beyond the nation. Intellectuals as a social group are the element of social structure in any civilized society" [18]. Karl Mannheim pointed at this in the beginning of the $\mathrm{XX}^{\text {th }}$ century. When describing the universal nature of intellectuals he examined them as the necessary cultural element of any society on a world-wide scale. In this context one should speak about the "Russian roots" in only that meaning where there is the distinction between the notion "intellectuals" and a "pointy head". Common understanding (, which is unifying here,) of the given social group is that these are people who are professionally busy with mental activity. One more connective junction is the definition of the intellectuals in society "... estate managers of the ruling group that were used for performing the subordinated functions of social hegemony and political governance." [15] 
The distinction of the notion "intellectuals" and "point head" are down to the functional peculiarities. In national science has been formed the tradition to define intellectuals as the moral and ethical phenomenon as intellectually social leader and this notion has the altruistic direction as Russian intellectuals are the conscience of the nation and they sacrifice their personal possessions for the public good without asking for something in return. According to western tradition it is accepted to mark the given social group as intellectuals putting the pragmatic sense into this notion: highlyeducated, cultural part of society engaged in professional mental activity distinguished from the other social groups in terms of stratification factors: earnings, property, material position and power. Utilitarian character to understand the role of intellectuals in society traces back to Weber's theory of social stratification, Marxian class theory and elite theories of G. Mosca and V. Pareto. Pragmatic character for the role of western intellectuals can be briefly marked as climbing to the top of social special class pyramid ("dominant elite", "the ruling") with the leaders who essentially influence the other social groups ("the guided") aimed to support the ruling group (assumption and retention of power). Intellectuals follow the achievement of their own prosperity, that is "for themselves" in comparison to the intellectuals who do this "for the others". The tendency of western researches has two directions: intellectuals influence society essentially (S. M Lipset, D. Bell) and intellectuals gradually lose their role and influence on society (W. Mills, E. Fromm). Within the limits of the given tendency there are developed theories where the leading role in the life of society plays either intellectuals-technocratic executives or intellectualshumanitarians.

One can highlight the following tendencies in the national sphere of social and political thinking when defying the place and the role of intellectuals in society: a) the crisis of self-identification for intellectuals, b) trust decrease to intellectuals on the part of the other social communities and groups. The difficulty of the situation is also in that the position of governance and society is often announced by the same representatives of intellectuals who create their own understandings of governance and society. It makes some confusion of positions and it should be considered.

Extreme contrariety of positions in the views on intellectuals and the own role of intellectuals in their surroundings indicates the crisis of self-identification. National science today has the opinion that intellectuals as social category died (at all). This social group is "mythological" and it lost its status and role in society. There are intellectuals but there is no intelligentsia. In the mainstream of the last tendencies the notion "intellectuals" is more often substituted with the name "creative class". It is connected with that the notion "social group" itself does not have some definite limits and it is quite relative in the modern world. One cannot agree with it at least because there are still social groups of people who are professionally engaged in mental work. This is precisely why our position can be briefly expressed: intellectuals have always been, they still exist and they will be. To prove our position and to contradict the expectations about the dawning end of Russian intelligentsia it is seen in national science now that there is justified the point of view that intelligentsia not only exists but it must and can become the catalyst of social development [19]. From the one hand, "intellectuals can never live with the governance, as they say, in perfect harmony" [19] but from the other hand, many authors see the solution to the problem with the lack of intelligent leaders in engaging intellectuals into governance [20]. Famous Russian sociologis O. N. Yanitskiy underlines groundlessness of accusation made by some modern authors towards the intellectuals. "The leaders of "the third sector" (as O. N. Yanitskiy [21] calls the intellectuals) are the social base of political reforms. And constant criticism of this group leads to "strengthening the ideology of impatience in society and, thereby, breaks its culture" [21].

This contrariety of positions in the views and opinions is first of all connected with reluctance to part with the mythologema about special messianic role of intellectuals in Russian society as they are the bearers of morality who are eternally indebted to the nation. Such unreasonably high expectations provoke disappointment. Russian intelligentsia as community (we put aside some personal examples of great civil service) has never met these expectations and not only could avert the series of tragedies and catastrophes peculiar to Russian history in XIX-XXI centuries but directly participated in forming catastrophic trends in the development of Russia.

It is no wonder that we start with debunking myths to have a more realistic and non-pathetic look at the problem of intellectuals who live in modern Russia and their political role. Described above expectations are undoubtedly connected to some definite historical period and the "spirit of the epoch". Corporations with professionals engaged in intellectual activity: doctors, lawyers, for example, began forming as late as Middle Ages but if to give this social phenomenon some cultural mission, then, intellectuals appeared in $\mathrm{XIX}^{\text {th }}$ century to construct national identity. Later on, in $\mathrm{XX}^{\text {th }}$ century, intellectuals modeled class identity. According to $\mathrm{K}$. Marx, at that moment they fulfilled the role of the social group that did not belong to any class. Extraneity to any class interests let intellectuals take above-the-fray position and at least try to act as the arbiter.

The situation is different today. According to modern researchers intelligentsia is internally inhomogeneous through being affected by the stratification processes. "Upper middle class" and "lower middle class", "highstatus" and "low-status" - all these definitions underline close position of the first group to the ruling elite in terms of earnings, interests, world outlook and the second group is closer to working people. Does it mean that intellectuals as special social community, which appeared on the basis of the sign that constitutes them, do not really exist? If to generalize, the signs with the help of which national social scientists try to identify the intellectuals are: 1) education (not lower than vocational secondary); 2) recognizing special obligations to the people; 3) active social positioning that is necessarily opposite to the governance of all the levels. 
High level of education individualized to the highest standard and raised people with the culture of reading books over the rest people in all the centuries. This level allowed differentiating between the insiders and the outsiders, thus, helping to form peculiar identity. The more educated people appeared the lower became their prestige value. One of the significant Russian scientists who researched the phenomenon of intellectuals, G. T. Toshenko, showed the way the processes happening in educational sphere placed this conventional and generally accepted criterion in doubt. Higher education sector began to grow rapidly in the middle of 1990-s. It resulted in that almost all the secondary school graduates were submerged by higher educational establishments. The quality of education, of course, was falling down and the amount of people who formally had higher education was increasing [22]. After dismantling the Soviet system, knowledge, the same way as in the other capitalist countries, turned into the item of goods but its Russian variant was less expensive, more accessible, and, hence, its prestige value lowered. It was still Paul Lafargue who in his work "Socialism and the Intellectuals" wrote that everything including mental abilities turns into the goods under capitalism. This kind of goods has the same laws of supply and demand that the others have. The more offers, the lower price. [23]

If we turn to the notions "high-status" intellectuals, "upper middle class" we refer them, then, to lawyers, doctors who organize private health care facilities, etc. To achieve such advances, both professional and financial, it is required, of course, to have intelligence and education but entrepreneurial spirit is first of all. And this quality makes "high-quality" intellectuals be kin mostly with the bourgeoisie than with state-paid workers. It significantly defines their harmony of interests, lifestyle and, maybe, political preferences.

As to the state-paid workers who are traditionally referred to the intellectuals such as teachers and doctors, they lost not only the feeling of having been chosen by their education but they also were thrown away to the lower social class. So, we will not generally submit complaint to them about the reason why they do not feel their duty to society and are not the bearers of a special mission in it.

According to Gramsci, Russian intellectuals appear on a strong national base (culture, spirituality, and historical connection to their people) but it is formed under the influence of "European experience" that is gained by pioneer, energetic and active social elite through the inheritance of western culture and progressive experience. "The most active, energetic, entrepreneurial and organized elite representatives go abroad where they acquire the culture and historical experience of the most developed western countries and, by doing so, they do not lose their national uniqueness and do not break emotional and historical connections with their people. By completing in such a way their intellectual apprenticeship they turn back home and make people come out of sleep and start rapidly and uninterruptedly move onward" [23]. As Gramsci describes national forces in Russia as inert and passive we can assume that that these are just organic intellectuals who have the role of locomotive able to change the existing political order and "inspire" the populace to struggle. (Note of the authors: Gramsci does not have a distinctive suggestion for the given fact).

Despite the long lapse of time we believe the topicality of the offered by Gramsci differentiation of intellectuals into traditional and organic to be reasonable and noteworthy. We will explain why.

Firstly: Traditional intellectuals in Russia were hundreds of years ago and still exist. These are famous public figures, scientists, writers, journalists, the very same "salt" (of the Russian land) and the conscience of the nation. These are mostly state-paid workers who are dependent on governance in the ordinary sense of the word.

We see peculiar features of modern traditional intellectuals in the following:

$\checkmark \quad$ too close in their strata;

$\checkmark$ no communication between the representatives of traditional intellectuals from different professional groups;

$\checkmark \quad$ information exchange and discussions in the sphere of traditional intellectuals are narrowly limited within the constraints of their professional group;

$\checkmark \quad$ the range of interests is also limited within the constraints of their professional group;

$\checkmark$ bad possibilities for adapting to competitive business environment;

decrease of prestige and the status of professions connected to mental work that provokes descending social mobility of this social layer;

$\checkmark$ fear for the consequences after expressing their own opinions;

$\checkmark$ unequal (for modern realias) budget financing and salary that causes the fear of unemployment and fatality to hand-to-mouth existence;

$\checkmark$ passive.

Secondly: Organic intellectuals are the most energetic and entrepreneurial "elite" that Gramsci was writing about. They consist of business representatives, middle level civil servants; privately practice lawyers, doctors, show business representatives, that is those who are often defined as "high-status" intellectuals or "upper middle class". These high-status intellectuals act in the modus of "calculating success" [6]. They portray themselves to be independent from governance but this independence is imaginary as in contrast to traditional intellectuals they do not have reliable moral base and, accordingly, easily come under engagement.

Peculiar features of modern organic intellectuals: $\begin{array}{cll}\checkmark & \text { have developed communication } \\ \text { network; } & & \\ \checkmark & \text { provide information exchange in }\end{array}$ different social strata; enlarge the range of interests, thus, providing attention from different social groups; have the possibility of fast reacting, momentary response to any problematic situation; use verbal and non-verbal means of influencing public consciousness; 


\section{$\checkmark \quad$ active.}

\section{Intellectual equilibrium}

We noticed that Gramsci marks the full absence of traditional intellectuals when researching the origin of intellectuals in USA. In his opinion this fact affected the intellectual equilibrium of forces. But as to USA, the given problem was being pulled through with merging different culture types into the single one national culture and as to Russia where traditional intellectuals formed historically as social community eliminating intellectuals from their "cultural heart" means breaking intellectual equilibrium of forces. It can lead to disastrous consequences.

Political role of organic and traditional intellectuals in Russia is determined with the ratio of socio political forces that are currently conquering or trying to save the hegemony at this definite historical moment.

Antonio Gramsci uses the very keen epithet in relation to the Russian nation when he calls inert and passive national forces as "Russian aspic". In our opinion the given epithet reflects the gist of Russian traditional intellectuals in the most exact way. How to overcome inactivity and historical inertia of traditional intellectuals? Surely, "intellectual struggle is ineffectual if it is carried out without the real struggle that tends to change the situation fundamentally". [15] How to create ideology in the environment of organic intellectuals?

The problem is how it is possible to merge these two kinds of intellectuals and whether it is necessary to do it.

\section{Conclusions}

What do we have as the final analysis? Did some other signs that constitute intellectuals appear in the current discussion field?

If to take as the point of reference of our analysis that Russian intellectuals exist as the elements of social culture, as social community that is qualitatively different from the other communities, then, it should be at least one sign peculiar to all the members of this community and not peculiar to the representatives of other communities. The presence of higher professional education and mental, not physical work character can be such a structural sign. If to use this sign we will get some static image of society. But it will tell us few things about the processes happening in society and about the roles of intellectuals in these processes.

Current state of society, which is constantly developing [24], changing its elementary membership, regrouping and functionally changing, requires recreating not so much its static as its dynamic image of society. We offer the approach to distinguishing social community intellectuals from the point of view of functional criteria. What is the role of intellectuals in Russian society nowadays?

We believe that intellectuals have two most important functions in society: stabilizing the social system and its critical analysis. It is evident that these functions have different vectors of direction; therefore, we differentiate two types of intellectuals with the help of Gramsci. As intellectuals have the cultural capital it advantages them to fulfill the stabilizing function. This function is performed by a teacher at school when he or she shares the accumulated cultural capital with his or her pupils, by a writer who implants "eternal values" to his or her readers, by an archeologist who carefully purges century-old over-placements from some clay shard, etc. This function is performed by an intellectual co-opted into governance as his activity is aimed, first of all, at supporting the current samples. We call this group of intellectuals "traditional intellectuals" not contradicting the author's position of A. Gramsci. Intellectuals who are practically oriented at public criticizing the current system (through mass media, participation in different social movements, selfregulating organizations, party activities, etc.) - are "organic" intellectuals. Their critical function is totally directed at transforming the system. Society needs both the performers of stabilizing function and those who will as if force it to changes. The question of balance is left. Anyway, Russian discourse about that a point head who does not criticize civil orders - is not the intellectual, looks like an artificial idea from this point of view.

Intellectuals as special social community the same way like all the modern society is in the state of constant becoming [25]. It is dynamic structure with the internal contradictions and the problems of reproduction. In our opinion, nonfulfillment of critical function by traditional intellectuals happens because of the following causes: distrust in relation to governance, anxieties, understanding the inefficiency of intentions, unbelief into the possibility to change something, fear for the consequences of expressing your opinion.

Besides, the absence of demand for mentally working people in Russia - is the negative tendency that has already been formed during some decades. It is confirmed by unequal (for modern realias) budget financing and salary. Accordingly, there is the fear in the environment of traditional intellectuals to lose even their current possessions as unemployment factually means fatality to hand-to-mouth existence. It leads to reducing prestige and the status of professions connected to mental work. The example of Soviet past: University professor got the salary ten times higher than a commercial worker or an accountant. Besides, professors were respected and esteemed in Soviet society. Modern realias: University professor gets the salary of about the same level like a salesman, an accountant or a mediumlevel manager, none of them spending decades for studying and professional development. Respect and esteem - are in the past, the loss of image and former status - are at present.

There is ideological deficit in the environment of organic intellectuals and this deficit is expressed in the lack of worldview ideas and spiritually-oriented aims [26].

The two offered social types of modern intellectuals are not autonomous in relation to each other. Every intellectual who has some cultural background and able to knowledge and information supported analysis of social system decides for him- or herself in every period of his or her life what position and in relation to what system unity with its elements to take: aimed at saving 
the system or its transformation. We do not have the unambiguous answer for the raised question. We think that this topic needs further understanding and researching.

\section{References}

1. IPSA Congress theme: Challenges of Contemporary Governance (2014) URL: http://www.ipsa.org/events/congress/montreal2014/t $\underline{\text { heme }}$

2. IPSA Summary - Montréal 2014 (2014) URL: http://www.ipsa.org/events/congress/montreal2014/s ummary-montr\%C3\%A9al-2014

3. M. A Gonzalez-Hernando, New Crisologie after 2008? Crises and Cognitive Autonomy (2014) URL: https://isaconf.confex.com/isaconf/wc2014/webprog ram/Session3841.html

4. IPSA Blueberry Soup - Documentary Movie Presentation (2014) URL: http://www.ipsa.org/myipsa/events/montreal2014/special/blueberry-soupdocumentary-movie-presentation

5. InoSMI.Ru, Finansovyi kriziz ne razrushit stranu Islandia v 2008 godu, December18 (2014) URL: http://inosmi.ru/overview/20141218/224998502.htm 1

6. M. Weber, Basic Sociological Terms. In Economy and society; an outline of interpretive sociology (Bedminster Press, New York, 1968)

7. M. Foucault, L'Arc, 70, (1977)

8. P. Bourdieu, Les Règles de l'art, genèse et structure du champ littéraire (Paris, Seuil, 1992)

9. P.Bourdieu, L.J.D. Wacquant, Réponses. Pour une anthropologie réflexive (Seuil, Paris, 1992)

10. M. Foucault, Une histoire de la vérité (Paris Syros, 1985)

11. Robert K. Merton, Social Theory and Social Structure (Free Press, New York, 1968)

12. T. Suzuki, Intellectuals in Gramsci's Prison Notebooks: An Active Relationship As a Key Concept. URL: https://isaconf.confex.com/isaconf/wc2014/webprog ram/Session3841.html

13. M. Bamyeh, The Social Role of Organic Intellectual: Four Amendments to Gramsci. URL: https://isaconf.confex.com/isaconf/wc2014/webprog ram/Session3841.html

14. XVIII ISA World Congress of Sociology: Facing an Unequal World: Challenges for Global Sociology. URL:

https://isaconf.confex.com/isaconf/wc2014/webprog $\mathrm{ram} /$ Session3841.html

15. A. Gramsci, The Prison Notebooks. 3 parts, Part 1. Translation from Italian by G. P. Smirnova and others. Endorsed by M.N.Grezkiy and L.A.Nikititch (Moscow, Politizdat, 1991)

16. N.A Berdyaev, The origins of the sense of Russian communism (Moscow, Nauka, 1990)

17. V. Dahl, Explanatory Dictionary of the Great Russian language. Part 2 (St. Petersburg, Volfa publication, 1881)
18. Social status and image of humanitariansintellectuals: illusions and reality. Panel Discussion in Russian State University for the Humanities. http://ecsocman.hse.ru/data/446/699/1217/011Sots.p $\underline{\mathrm{df}}$

19. B. N. Bessonov, Vestnik of Moscow State Pedagogical University. The edition: Philosophic Sciences, 1 (7), (2013)

20. K.G. Bardakova, O.M. Goreva, Izvestia visshih uchebnih zavedeniy. Sociology. Economics. Politics, 4, (2010)

21. O.N. Yanitskiy, Nationwide Scientific and Political journal "Vlast", 12, (2013)

22. G. T. Toshenko, Journal "Sociology", 1, (2012)

23. P. Lafargue, "Socialism and Intelligentsia" Translation from French (Saint-Petersburg, Molot, 1906)

24. P. Sztompka, Society in Action: the Theory of Social Becoming (Cambridge, Polity Press, 1991)

25. I. Ardashkin, Proc. Soc. and Beh. Sc., 166, (2015) 